\title{
ENFORCEABILITY UNDER THE UNITED STATES ARBITRATION ACT: COLLECTIVE BARGAINING AGREEMENTS AND CONTRACTS NOT "INVOLVING COMMERCE"*
}

THE Federal Arbitration Act makes certain arbitration agreements binding on the contracting parties. ${ }^{1}$ Section 2 of the Act provides that written agreements to arbitrate which are incorporated in, or which relate to, "maritime transactions" or "contracts evidencing transactions involving [interstate or foreign] commerce" shall be "valid, irrevocable, and enforceable." - Section 1 excludes "contracts of employment of seamen, railroad employees, or any other class of workers [in such commerce]."3 The remaining sections of the Act establish procedures for enforcement of arbitration agreements and for confirmation and vacation of awards. ${ }^{*}$ These procedural sections refer to suits in federal courts, but do not specifically limit the operation of the procedures to controversies involving commerce. 5 Decisions interpreting the Arbitration Act conflict on two important issues: the statute's applicability to collective bargaining agreements ${ }^{\circ}$ and the availability of the enforcement

\footnotetext{
*Tenney Engineering, Inc. v. United Electrical R \& M. Wlars., 207 F.2d 450 (3d Cir. 1953).

1. The United States Arbitration Act was originally enacted as 43 Srar. 883 (1925), 9 U.S.C. $\$ 1$ et seq. (1946). It was re-adopted, 9 U.S.C. $\$ 1$ ct seq. (Supp. 1952) when Title 9 of the United States Code was enacted into positive law. See, generally, ABA, Comm. on Commerce, Trade and Commercial Law, The United States Arbitration Low and its Application, 11 A.B.A.J. 153 (1925); Cohen \& Dayton, The Nerv Federal Arbitration Law, 12 VA. L. REv. 265 (1926); Sturges \& Mfurphy, Some Confusisg Malfers Relating to Arbitration under the U.S. Arbitration Act, 17 Law \& Co:isesr. Prop. 580 (1952).
}

2. 9 U.S.C. $\$ 2$ (Supp. 1952).

3. 9 U.S.C. $\$ 1$ (Supp. 1952).

4. 9 U.S.C. $\$ \$ 3-14$ (Supp. 1952). Section 3, stay of proceedings where issue referable to arbitration; section 4, court order to compel arbitration; section 5, appointment of arbitrators; section 6, application to the court heard as a motion; section 7 , process for obtaining witnesses; section 8 , proceedings in admiralty begun by libel and seizure of vessel; section 9, confirmation of arbitrators' awards; section 10, vacation of awards; section 11, modification or correction of awards; section 12, notice of motions to vante or modify; section 13, filing of papers, force and effect of award; section 14, contracts made prior to January 1,1926 not affected.

5. See note 4 supra.

6. Compare Donahue v. Susquehanna Collieries Co., 138 F.2d 3 (3d Cir. 1943) (applicable to collective bargaining agreements); United Office \& Pro. Whirs. v. Monumental Life Ins. Co., SS F. Supp. 602 (E.D. Pa. 1950) (same), acith Gatliff Coal Co. v. Cox, 142 F.2d 876 (6th Cir. 1944) (inapplicable to collective bargaining agreements); Int'l Union v. Colonial Hardwood Flooring Co., 16S F.2d 33 (4th Cir. 1948) (same, alternative holding). 
sections to litigants in federal court who seek to enforce commercial arbitration contracts involving only intrastate commerce. ${ }^{7}$

In Tenney Engineering, Inc. v. United Electrical $R$. \& $M$. Workers, ${ }^{8}$ the Third Circuit attempted to resolve both of these problems. Employer sued union in federal district court for alleged breach of their collective bargaining agreement. ${ }^{9}$ Invoking Section 3 of the Arbitration Act, ${ }^{10}$ defendant moved for a stay of suit pending arbitration called for by provisions of the contract. Stay was denied, and defendant appealed. Sitting en banc, the Third Circuit reversed. Four judges, following the Greyhound cases, ${ }^{11}$ decided that the employment contract exception of Section 1 embraced collective bargaining agreements. ${ }^{12}$ By itself the effect of this holding would have been to maintain the narrow interpretation of the Act's coverage previously adopted.13 But by applying the ejusdem generis rule to the phrase, "seamen, railroad employees, or any other class of workers engaged in . . . commerce," the court determined that Section 1 excluded only the contracts of transportation workers. ${ }^{14}$ The total effect of their decisions on these two points was thus to weaken the thrust of the exclusion and expand the scope of the Act. Since the members of the defendant union were not transportation workers, the court held that the Section 1 exception was no bar to enforcement of the parties' arbitration clause. ${ }^{15}$ Two judges concurred in that conclusion on the ground that collective bargaining agreements were not "employment contracts."16 The two dissenters, on the other hand, thought that the defendant's

7. Compare In re Cold Metal Process Co., 9 F. Supp. 992 (W.D. Pa. 1935) (both $\$ 3$ \& 4 inapplicable to contracts not involving commerce); Zip Mfg. Co. v. Pep Mfg. Co., 44 F.2d 184 (D. Del. 1930) (same), with Agostini Bros. Bldg. Corp. v. United States, 142 F.2d 854 (4th Cir. 1944) ( $\$ 3$ held applicable to commercial arbitration contract not involving interstate commerce). But see Sturges \& Murphy, Arbitration inder the United States Arbitration Act, 17 LaW \& Contenrp. Prop. 580, 596-604 (1952).

8. 207 F.2d 450 (3d Cir. 1953).

9. Plaintiff sued under the Labor Management Relations Act, 61 STAT. 156 (1947), 29 U.S.C. $\$ 185$ (Supp. 1.952) ( $\$ 301 a$ ).

10. 9 U.S.C. $\$ 3$ (Sugp. 1952).

11. Pennsylvania Greyhound Lines v. Amalgamated Ass'n, 193 F.2d 327 (3d Cir. 1952); Amalgamated Ass'n v. Pennsylvania Greyhound Lines, 192 F.2d 310 (3d Cir. 1951).

12. Tenney Engineering, Inc. v. United Electrical R. \& M. Wkrs., 207 F.2d 450, 451-2 (3d Cir. 1.953).

13. See cases cited note 11 supra. See also Int'l Union v. Colonial Hardwood Flooring Co., 168 F.2d 33 (4th Cir. 1948); Gatliff Coal Co. v. Cox, 142 F.2d 876 (6th Cir. 1944).

14. Tenney Engineering, Inc. v. United Electrical R. \& M. Wkrs., 207 F.2d 450, 452 (3d Cir. 1953).

15. Id. at 453 .

16. Judge Maris, who delivered the opinion of the court, apparently held that collective bargaining agreements were employment contracts only out of deference to his brethren and against his own better judgment. According to Chief Judge Biggs's concurring opinion, Judge Maris thought a proper interpretation of section 1 would construe a collective bargaining agreement not to be a contract of employment. See Tenney Engineering, Inc. v. United Electrical R. \& M. Wkrs., 207 F.2d 450, 455 (3d Cir. 1953). 
arbitration provision could not be enforced, because Section 1 excluded all collective bargaining agreements from the Act. ${ }^{17}$

Once the first issue was decided, both the majority and concurring judges held that a contract does not have to involve foreign or interstate commerce to be enforceable by means of a stay of suit issued under Section 3 of the Act. Accordingly, they found it unnecessary to decide whether the Tcmicy employment contract involved such commerce. ${ }^{18}$ Under this interpretation, a federal court can stay proceedings in a suit before it in order to give effect to any arbitration contract not expressly put beyond the Act's reach by the employment contract exception of Section 1. Because the dissent had already concluded that collective bargaining agreements were specifically excluded from the Act, it did not discuss this second issue. ${ }^{19}$

The court's interpretation of "contracts of employment" to include collective bargaining agreements is the only tenable view. This broader meaning of the statutory phrase is its obvious and natural one.0 And to deny this construction would be to disregard the origin of the exception. Since it was inserted into the Act in deference to the demands of organized labor, it should be presumed to refer to the natural subject of labor's attention, the collective contract. Moreover, the alternative interpretation is unacceptable. The exception was added in committee, ${ }^{22}$ presumably to effect some change in the statute's coverage. It expressly mentions the contracts of "seamen [and] railroad employees." But if the statutory exception merely prevented enforcement of arbitration clauses in individual contracts of such workers, its inclusion was apparently useless. Hiring contracts of individual seamen or railroad employees-indeed, of employees in any mass industry-do not contain arbitration clauses. Arbitration is a time- and trouble-saving com-

17. Id. at $455-9$.

18. Id. at 454 .

19. See id. at $455-9$.

20. Amalgamated Ass'n v. Pennsylvania Greyhound Lines, $192 \mathrm{~F} .2 \mathrm{~d} 310$ (3d Cir. 1951) and cases cited therein; Gatliff Coal Co. v. Cox, 142 F.2d 876 (6th Cir. 1944). See Donahue v. Susquehanna Collieries, Co., 160 F.2d 661, 662 (3d Cir. 1947). See also Horton, Ripley \& Schnapper, Drctionary of Mfonern Ecosoxics 57 (1948). Contra: Lewittes \& Sons v. United Furniture Workers, 95 F. Supp. 851 (S.D.N.Y. 1951); United Office \& Pro. Wkrs. v. Monumental Life Ins. Co., \&8 F. Supp. 602 (E.D. Pa. 1950).

21. Hearings before Subcommittee of Conmsittee on the Judiciary ot S.4214, 67th Cong., 4th Sess. 9 (1923). The witness whose testimony against the bill prompted the amendment excluding contracts of employment was Andrew Furuseth, President of the International Seamen's Union. Mr. Furuseth's opposition to federal enforcement of labor arbitration agreement was of long standing. See Hcarings before Subcomusiltce of the Cossmsittee our Labor on H.R. 9491, 58th Cong., 1st Sess. (1904) fassins.

See also Gordon, Intermational Aspacts of Trade Arbitration, 11 A.B.A.J. 717, 718 (1925): "The proviso in [the Act] which excepts from its operation workers" agreements, while regarded by its framers as no improvement, was suggested by Herbert Hoover, Secretary of Commerce, a stanch friend of the measure, as a vise sop to the Cerberus of Labor."

22. Heariings on S. 4214, sipra note 21 . 
promise resorted to by parties of roughly comparable bargaining power. ${ }^{23}$ Only employee organization would force a large employer to forego customary prerogatives by submitting disputes to arbitration. ${ }^{24}$ Hence, arbitration provisions normally will be found only in collective contracts. Ascribing to Congress the intent to exclude only individual contracts of hire would therefore have been unreasonable.

While properly classifying collective bargaining agreements as "contracts of employment," Tenney arbitrarily limits the scope of the employment contract exception to transportation workers. ${ }^{25}$ Under the Tenncy rationale, arbitration agreements concerning workers employed in non-transportation industries involving "commerce" can be enforced. By applying the rule of ejusdem generis to the text of the exception the court inferred a Congressional intent to effect this differential treatment. ${ }^{20}$ But ejusdem generis is merely a rule of statutory construction. It cannot control where the intent it ascribes to Congress is disproved both by the incongruity which its application would produce and also by available legislative history. ${ }^{27}$

The legislative history of the Arbitration Act indicates that Congress intended to exclude all employment contracts from its operation. A representative of the drafters of the statute stated: "It is not intended that this shall be an act referring to labor disputes, at all." ${ }^{28}$ To clarify this intent he suggested an amendment which excluded "seamen or any class of workers engaged in foreign or interstate commerce" but made no mention of railrond employees. ${ }^{29}$ The form of the amendment was clearly dictated by a desire to parallel Section 2, which declares that the provisions of the Act apply to "maritime transactions" and "contracts . . involving commerce."30 Cast in such language, the amendment ensured that Section 1 would exclude all employment contracts which Section 2 would otherwise have brought within

23. See Feinsinger, Book Review, 5 STAN. L. REv. 863, 864 (1953): "[T] he function of arbitration [is] as a substitute for the strike or lock-out, and the agreement to arbitrate [is] the quid pro quo for the no-strike, no-lockout clause."

24. See Hearings before Subcammittee of the Committee on Labor on H.R. 9491, 58th Cong., 1st Sess. 1 (1904) passim.

25. This is the first case so to hold, although this view may have been intimated in United Office \& Pro. Wkrs. v. Monumental Life Ins. Co., 88 F. Supp. 602, 606 n.4 (E.D. Pa. 1950) and Amalgamated Ass'n v. Pennsylvania Greyhound Lines, 192 F.2d 310, 313-4 (3d Cir. 1951). Even with this foreshadowing, however, at least one district court understood the Greyhound cases to exclude all collective bargaining contracts. Ludlow Mfg. \& Sales Co. v. Textile Workers Union, 108 F. Supp. 45, 49 (D. Del. 1952).

26. Tenney Engineering, Inc. v. United Electrical R. \& M. Wkrs., 207 F.2d 450, 452-3 (3d Cir. 1953).

27. United States v. Alpers, 338 U.S. 680 (1950); SEC v. C. M. Joiner Leasing Corp., 320 U.S. 344 (1943); Mid-Northern Co. v. Montana, 268 U.S. 45 (1925).

28. Testimony of W. H. H. Piatt, Chairman, ABA, Comm. on Commerce, Trade and Commercial Law in Hearings before Subcommittee of the Committce on Judiciary on $S .4214,67$ th Cong., 4th Sess. 9 (1923).

29. Ibid.

30. 9 U.S.C. $\$ 2$ (Supp. 1952). 
the purview of the bill. Only if the later addition of the phrase "railroad employees" indicated a newly formed desire to limit the scope of the exclusionary clause to transportation workers, could ejusdem gencris justifiably be invoked. ${ }^{31}$ But if that had been the motive for changing the amendment into its final form, the drafters could have made their purpose much clearer by a far less subtle use of words. Ejusdcm generis thus misrepresents legislative intent.

The Tenney court speculated that Congress intended to limit the employment contract exception to transportation workers in order to exclude only those classes of employees for whom statutorily created arbitration procedures already existed. That reasoning is unpersuasive. Such procedures were available only to seamen and railroad workers, ${ }^{32}$ the two classes specifically named. Had the legislative purpose been that hypothesized by the court, Congress would not also have excluded "any other class of employees,"3s iworkers for whom no such procedure was provided. Furthermore, the separate arbitration procedure previously established for railroad employees was inapplicable to employment contracts. ${ }^{31}$ Hence it was not comparable to the enforcement machinery which the court held to be provided by the Arbitration Act for the employees of non-transportation industries. The inadequacy in the Third Circuit's rationale, plus the contrary legislative history, ${ }^{35}$ indicate that the court misapplied the cjusdem gcneris rule.

Going further, Tenney reaffirmed a view ${ }^{3 B}$ on which the Third Circuit's own Greyhound decisions ${ }^{37}$ had cast some doubt. The doubt arose in the following fashion. Section 1 of the Arbitration Act defines commerce. Originally the Third Circuit considered the clause excluding "contracts of employment" as a subtraction from the scope of "commerce" and thus part of this definition. ${ }^{38}$ It was also the court's position that Section 3 could be used to enforce an arbitration agreement even though the contract did not involve commerce as defined in Section 1. Therefore, the fact that a labor arbitration

31. See note 27 supra and accompanying text.

32. Rev. Stat. $\$ 4554$ (1875) (seamen); 38 Stat. 103-10\$ (1913) (railroad vorliers); see also 41 Stat. 469 (1920). See note 4, supro.

33. 9 U.S.C. $\$ 1$ (Supp. 1952).

34. The relevant provision of 38 STar. 103-108 (1913) referred only to agreements to arbitrate existing disputes. The arbitration clause of a collective bargaining agreement normally provides for the arbitration of future disputes.

"Adjustment Boards" and a "Railroad Labor Board" existed for the settlement of labor disputes. 41 Star. 469 (1920). But their operation was neither dependent on, nor directed toward, the enforcement of arbitration agreements.

35. See text at notes 28-31 supra.

36. Watkins v. Hudson Coal Co., 151 F.2d 311 (3d Cir. 1945) ; Denahue v. Susquehanna Collieries Co., 138 F.2d 3 (3d Cir. 1943). See also Agostini Bros. Bldg. Corp. v. United States, 142 F.2d 854 (4th Cir. 1944).

37. Pennsylvania Greyhound Lines v. Amalgamated Ass'n, 193 F.2d 327 (3d Cir. 1952); Amalgamated Ass'n v. Pennsylvania Greyhound Lines, 192 F.2d 310 (3d Cir. 1951).

38. Watkins v. Hudson Coal Co., 151 F.2d 311 (3d Cir. 1945); Donahue v. Susquehanna Collieries Co., 138 F.2d 3 (3d Cir. 1943). 
agreement was a "contract of employment"-and thus expressly excluded from the Section 1 definition of commerce-was held to be no bar to enforcement under Section $3 .^{39}$ But in the Greyhound cases, the Third Circtit in effect reversed its prior position by holding that a "contract of employment" could not be enforced under any section of the Act (including Section 3). But the court did not expressly repudiate its previous holdings that the exclusionary clause of Section 1 is part of the definition of commerce. ${ }^{41}$ Hence, the Greyhound decisions might have been thought to imply that the Third Circuit would deny Section 3 enforcement to any contract not within the definition of commerce. Tenney precludes such an inference by holding that Section 3 makes a stay of proceedings available to a litigant in federal court even when the contract in dispute involves neither a maritime transaction nor interstate commerce. ${ }^{42}$

However, Tenney's interpretation of Section 3 frustrates the Congressional intent, expressed in the "contract of employment" clause of Section 1, to exclude all employment contracts from the purview of the Act. ${ }^{43}$ By its terms, the exception refers only to the contracts of workers "engaged in foreign or interstate commerce." 44 If Tenney were correct in holding that contracts which do not involve such commerce can be enforced under Section 3 , then employment contracts of workers engaged solely in intrastate commerce would be enforceable if sued on in federal court. But creating such an illogical distinction between the contracts of interstate and intrastate employees imputes to Congress an unreasonable purpose ${ }^{45}$ and contradicts both implicit

39. See cases cited note 38 supra.

40. Pennsylvania Greyhound Lines v. Amalgamated Ass'n, 193 F.2d 327 (3d Cir. 1952); Amalgamated Ass'n v. Pennsylvania Greyhound Lines, 192 F.2d 310 (3d Cir. 1951).

The rationale was that Congress had amended the statute by enacting the compilers' catch-line when it enacted Title 9 of the United States Code into positive law. The catch-line reads "exceptions to title." This was thought to be a manifestation of a congressional intent to overrule the Third Circuit's view that the exclusionary clause was only an exception from section 1 of the Act, the definition of commerce. See Sturges \& Murphy, Arbitration under the United States Arbitration Act, 17 LAw \& Contzmp. Proв. 580, 616 n.80 (1952).

41. Pennsylvania Greyhound Lines v. Amalgamated Ass'n; Amalgamated Ass'n v. Pennsylvania Greyhound Lines, supra note 40.

Section 1 reads: ". . . 'commerce', as herein defined, means commerce among the several states or with foreign nations, or in any Territory of the United States or in the District of Columbia, or between any such Territory and another, or between any such Territory and any State or foreign nation, or between the District of Columbia and any State or Territory or foreign nation, but nothing herein contained shall apply to contracts of employment of seamen, railroad employees, or any other class of workers engaged in foreign or interstate commerce." 9 U.S.C. $\$ 1$ (Supp. 1952).

42. Tenney Engineering, Inc. v. United Electrical R. \& M. Wkrs., 207 F.2d 450 (3d Cir. 1953).

43. See text at notes 28-31 supra.

44. See note 41 supra.

45. In 1925, when the United States Arbitration Act was passed, the concept of "interstate commerce" was narrower than it is today. A greater proportion of the working 
and explicit legislative intent. ${ }^{46}$ Courts should respect this intent by holding that the Act can be invoked only to enforce a contract which involves either interstate commerce or a maritime transaction. ${ }^{17}$

Adopting this interpretation in order to effectuate Congressional intent to exclude employment contracts need entail only a negligible reduction in the number of commercial arbitration contracts enforceable in federal courts. Section 2 should be interpreted as creating a substantive federal right derived from Congress's plenary power over interstate commerce. ${ }^{48}$ Since in enacting the statute Congress attempted to provide enforcement for as many commercial arbitration contracts as possible, it sought to use the full extent of its

force would have been considered as engaged in intrastate commerce. To have excluded only workers in interstate commerce would therefore have been even more illogical in 1925 than it would be now.

46. One problem of consistency remains unresolved. Section 1 defines commerce to include foreign, interstate, and territorial commerce; but the employment contract exception excludes only employment contracts in foreign and interstate commerce Does this mean that the Act makes arbitration agreements of workers in territorial commerce enforceable? Perhaps "interstate or foreign commerce" should be interpreted as a shorthand expression meaning all the commerce which Congress may constitutionally regulate. The employment contract exception was clearly framed on the assumption that the Act applied only to commerce within the regulatory power of Congress. Hearings before Srbcommittee of the Committee on the Judiciary on S.4214, 67th Cong., 4th Sess. 9 (1923).

47. Another facet of the Act's legislative history also tends to prove that it was intended to apply only to contracts involving maritime transactions or forcign or interstate commerce. The House version of the bill made its provisions applieable to contracts involving interstate commerce or within the jurisdiction of admiralty, or which may bc the subject of litigation in federal courts (emphasis added.) H.R. REP. No. 96, 68th Cong., 1st Sess. 1 (1924) ; 65 CoNG. Rec. 11081 (1925). But the Act finally passed was made to conform to the Senate version by deletion of this third category, exntracts the subject of litigation in federal courts. 66 Cosg. Rec. 2759-62, 3003-4. The purpose of the Senate Bill was to make only the first two categories enforceable. SE:r. REP. No. 536, 68th Cong., 1st Sess. 2 (1924). The subsequent difficulties which the courts have experienced in construing the Act have no doubt been caused by an imperfect reconciliation of the two versions.

Sturges \& Murphy reach the same conclusion on other grounds. See Some Confusing Matters Relating to Arbitration under the U.S. Arbitration Act, $17 \mathrm{LaW} \&$ Conisurp. Prob. 580, 598-604 (1952). See also Kochery, The Enforcentent of Arbitration in the Federal Courts: Erie v. Tompkins, 39 Corseur L.Q. 74 (1953).

48. See Agostini Bros. Bldg. Corp. v. United States, 142 F.2d 854, 856 (4th Cir. 1944) ; Donahue v. Susquehanna Collieries Co.. 138 F.2d 3, 5 (3d Cir. 1943); Jad:son v. Kentucky River Mills, 65 F. Supp. 601, 603 (E.D. Ky. 1946); H.R. REp. No. 96, 68th Cong., 1st Sess. 1 (1924) ; SeN. KeP. No. 536, 6Sth Cong., Ist Sess. 1 (1924). Cf. Tesas Development Co. v. MIcGough Bros., 165 F.2d 276 (5th Cir. 1947).

Several cases have termed arbitration under the Act procedural or remedial. See Murray Oil Products Co. v. Mitsui \& Co., 146 F.2d 381, 383 (2d Cir. 1944); Parry v. Bache, 125 F.2d 493, 495 (5th Cir. 1942) ; Boston \& Maine Transp. Co. v. Amalgamated Ass'n, 106 F. Supp. 334, 336 (D. Mass. 1952); Wilson \& Co. v. Fremont Calie \& Meal Co., 77 F. Supp. 364, 379 (D. Neb. 194S). But the contention made in the test is only that contracts which evidence transactions involving commerce are made enforceable 
commerce power. ${ }^{49}$ As the scope of that power has been enlarged by judicial decision, the reach of the Arbitration Act has grown commensurately. ${ }^{\circ 0}$ Under presently accepted conceptions of the commerce power, there will be few commercial arbitration contracts which must be held unenforceable because they do not "involve commerce." 51

Finally, treating Section 2 as having created a substantive federal right may make arbitration contracts involving interstate commerce enforceable in state courts. The Arbitration Act has been held not to confer federal jurisdiction in itself. ${ }^{52}$ And explicit enforcement provisions of the Act are by their terms available only to litigants in federal court. ${ }^{53}$ But the statement in Section 2 that arbitration contracts covered shall be "valid, irrevocable,

under the congressional power over interstate commerce rather than under the power to regulate the procedures in the federal courts. But see Krauss Bros. Lumber Co. v. Louis Bossert \& Sons, 62 F.2d 1004, 1006 (2d Cir. 1933) (implies that the Act does not depend on the commerce power).

49. See Tenney Engineering, Inc. v. United Electrical R. \& M. Wkrs., 207 F.2d 450, 454. See also H.R. REP. No. 96, 68th Cong., 1st Sess. 1 (1924): "[The enforcement of arbitration] reaches not only the actual interstate shipment of goods but also contracts relating to interstate commerce."

50. A suit for breach of contract is not a cause of action arising under the laws of the United States even if the defense is provided by federal statute (c.g., an agreement to arbitrate). Gully v. First Nat. Bank, 299 U.S. 109 (1936). Therefore two conditions must be met for the United States Arbitration Act to be available for the enforcement of an arbitration agreement in a federal court. The contract in dispute must evidence a transaction involving interstate commerce or within the jurisdiction of admiralty (at least if any section except 3 is to be invoked, see pages 733-4 supra) and the controversy must be one over which the federal courts would have jurisdiction in the absence of an arbitration clause. See Krauss Bros. Lumber Co. v. Louis Bossert \& Sons, 62 F.2d 1004, 1006 (2d Cir. 1933), 3 Moore, Federal Practice 3426 n.12 (1st ed. 1938). If the second requirement were an indication that the Act was to operate on the basis of Congress's constitutional power over the federal courts, the first requirement, that the contract in dispute also involve commerce, would be a mere limitation on the scope of the Act, without any jurisdiction-conferring purpose. As a limitation, "interstate commerce" would have to be interpreted as it was meant by the enacting Congress. The term as used in the Act would therefore comprehend only such transactions as were understood to involve interstate commerce at the time of its enactment. Many contracts which today would be held to involve such commerce would be excluded from the purview of the Act. On the other hand, if the requirement that the controversy be justiciable in the federal courts aside from the arbitration clause is the limitation, "interstate commerce" is the constitutional basis of the Act. Then, since Congress sought to use its power over such commerce to its fullest extent, the reach of the Act must extend to whatever limits the concept is held to have at any given time.

51. See Wilko v. Swan, 74 S. Ct. 182, 183 (1953) ; 62 Yale L.J. 985 (1953). Plaintiff had been induced to enter into a margin agreement for the purchase of stock as a result of solicitations sent through the channels of interstate commerce. The margin agreement was therefore a "contract evidencing a transaction involving commerce" within the meaning of the Arbitration Act.

52. San Carlo Opera Co. v. Conley, 72 F. Supp. 825 (S.D.N.Y. 1946), aff'd per curiam, 163 F.2d 310 (2d Cir. 1947).

53. See especially sections 3 and 4, 9 U.S.C. $\$ \$ 3,4$ (Supp. 1952), which refer to "court[s] of the United States." 
and enforceable" contrasts with common law treatment of arbitration agreements. ${ }^{54}$ That provision is sufficient to indicate that the Act malies contracts involving commerce subject to state remedies in the nature of specific performance, the precise form of which can be determined by consulting state decisional and statutory law. ${ }^{55}$ Such an interpretation would greatly enlarge the number of arbitration agreements made enforceable by the Act.

Tenney contorts the Arbitration Act in an unjustified effort to render labor arbitration contracts enforceable. If the public policy enunciated by Congress in passing the Act has changed so that it now favors enforcement of such agreements, the remedy lies in legislative amendment, not judicial manipulation. ${ }^{\text {56 }}$ Cases may often arise which are not specifically covered by general legislation. Then the courts must interpret the applicable legislation broadly to effectuate the over-all policy which Congress has chosen. But this necessity is not a license to fly in the face of an explicit statutory prohibition whose limits are defined by its context and legislative history. Certainly the implementation of public policy does not require the strained and inconsistent interpretation which the Third Circuit has given the Arbitration Act.

54. 9 U.S.C. $\$ 2$ (Supp. 1952); SeN. Rep. No. 536, 6Sth Cong., 1st Sess. 2 (1924).

55. A federal statute enacted under a delegated power is enforceable in state court even where the statute relates to the "remedy" (penalty), rather than to the "right," Testa v. Katt, 330 U.S. 386 (1946), and despite any state policy contrary to the policy and purpose of the federal act, U.S. Coxst. Art. VI, \$2, Miondou v. New Yorl, N.H. \& H.R.R., 223 U.S. 1, 55-9 (1912). A state court has jurisdiction to enforce a federal right unless exclusive jurisdiction in the federal courts is required by the Constitution or by intent of Congress, expressly or necessarily implied. Claflin v. Houseman, 93 U.S. 833 (1876).

No congressional intent to exclude state enforcement of the Arbitration Act is expressed therein and it is not clear that such an intent is necessarily implied. The Report of the House Committee on the Iudiciary, H.R. REP. No. 95, 6Sth Cong., 1st Sess. 1 (1924), speaks of the Act as being procedural and enforceable by the courts of the United States. But this intent to pitch the statute on a procedural level was presumably abandoned when the Act was amended to make it applicable only to contracts involving commerce. An intent to vest exclusive jurisdiction in the federal courts can be inferred, if at all, solely from the fact that the procedural sections of the Act refer only to courts of the United States. But note that the Bankruptcy Act, "14 Srar. 517 ef scq. (1867), under which suit was brought in Claflin v. Houseman, suspra, seems to imply exclusive federal jurisdiction at least as strongly as the Arbitration Act. See also The Miaccabees v. City of North Chicago, 125 F.2d 330 (7th Cir. 1942) (state substantive right an be enforced in federal court despite the fact that the sole remedies provided by the same statute are available only in state court). Bunn, National Low of Unfair Compatition, 62 HARv. L. Rev. 987 (1924), suggests an interpretation of the Federal Trade Commission Act which is analogous to the interpretation of the Arbitration Act contended for here. $\mathrm{He}$ argues that the practices declared illegal by the FTCA are broader than the remedies provided; therefore unfair trade practices affecting commerce should be actionable by private parties in federal court or in state courts under federal law.

The only reported attempt to invole the United States Arbitration Act in state court failed, however. Wilson \& Co. v. Fremont Cake \& Meal Co.. 153 Neb. 160, 43 N.W.2d 657 (1950), cert. denied, 342 U.S. $\$ 12$ (1951).

56. But see Cox, Griecance Arbitration in the Federal Courts, 67 Hanv. L. Rev. 591 (1954). 